\title{
Lariniophora, a new monotypic orb-weaving spider genus from Australia (Araneae: Araneidae: Araneinae)
}

\author{
Volker W. Framenau \\ Department of Terrestrial Zoology, Western Australian Museum, Locked Bag 49, Welshpool DC, \\ Western Australia 6986, Australia. Email: volker.framenau@museum.wa.gov.au \\ School of Animal Biology, University of Western Australia, Crawley, Western Australia 6009, Australia. \\ Present address: Phoenix Environmental Sciences Pty Ltd, 1/511 Wanneroo Road, Balcatta, Western \\ Australia 6021, Australia.
}

\begin{abstract}
A new monotypic genus of orb-weaving spider (Araneidae Clerck, 1758) within the subfamily Araneinae Clerck, 1758 is established: Lariniophora, with L. ragnhildae (Strand, 1917) as type and sole species. The somatic morphology of Lariniophora is similar to Larinia Simon, 1874 and allied genera, however, their genitalia differ considerably. A phylogenetic analysis established close a relationship between Lariniophora and Eriophora Simon, 1864 with which it shares a paramedian apophysis as a long basal extension of the conductor in the male pedipalp. The epigyne is unique within the Araneidae and is composed of an elevated plate and a narrow long scape. Specimens of L. ragnhildae have mainly been found in arid regions of Western Australia but also in the Northern Territory, Queensland, and South Australia. Here these spiders built a conventional orb-web in low shrubs and grassland. Mature spiders have been found between February and October suggesting reproductive activity in winter.
\end{abstract}

KEYWORDS: Eriophora, taxonomy, paramedian apophysis, coxal hook clade.

\section{INTRODUCTION}

With some 2,800 species in 166 genera, orb-weaving spiders (family Araneidae Clerck, 1758) represent one of the largest spider families world-wide (Platnick 2010). The subfamily Araneinae Clerck, 1758, which forms one of two major clades of the Araneidae in addition to an 'argiopoid clade', is the most speciose subfamily (Scharff and Coddington 1997). Araneinae contain the 'typical' orb-weaving spiders: largely nocturnal, active and fast predators and spinners of conventional orbwebs. During the day, they usually rest in a camouflaged retreat away from the hub (Scharff and Coddington 1997).

Despite their omnipresence throughout the country, the taxonomic and systematic knowledge of Australian Araneinae is rudimentary. Some 150 species are described with about two thirds of these currently misplaced in the 'dump' genus Araneus Clerck, 1758. Some taxonomic work has recently been published on the Australian Araneinae (Framenau and Scharff 2008; Framenau et al. 2010a; Smith and Levi 2010) and other orb-weaver subfamilies of the region (Smith 2006; Framenau 2008; Harmer and Framenau 2008; Framenau and Scharff 2009; Framenau et al. 2009, 2010b). However, the most recent key to the genera of eight families of Australian Orbiculariae is more than 15 years old and only allows a generic level identification of some Araneidae, including 11 genera of Araneinae (Davies 1988). Due to a lack of detailed taxonomic studies, the key does not provide any further aid in the identification of the almost 100 Australian species of Araneus, which were represented by only a single species, Araneus eburnus (Keyserling, 1886). At the same time Davies (1988) acknowledged the misplacement of Australian Araneus as the many local species within this genus have a paramedian apophysis on the male pedipalp (absent in true Araneus) and a single tibial spine on the pedipalp (two spines in Araneus) (e.g. Levi 1991).

A recent revision of Australian orb-weaving spider genera with affinities to Larinia Simon, 1874 as part of a comprehensive revision of Australian Araneinae (Framenau and Scharff 2008), revealed a species with very similar, "larinoid" somatic morphology, i.e. elongated carapace and abdomen and overall greenish colouration, in Australian museum collections, which was frequently misidentified as Larinia. However, 
genital morphology of this species is considerably different to Larinia and allied genera (e.g. Grasshoff 1970, Harrod et al. 1991). The male pedipalp has a paramedian apophysis as a long basal extension of the conductor suggesting close affinities with Eriophora Simon, 1864 or Verrucosa McCook, 1888 (e.g. Levi 1970, 1976, 1985). Some of the most common Australian orb-weaving spiders are currently listed in the genus Eriophora (e.g. Davies, 1980); however, recent molecular studies have shown that Australasian representatives of this genus are not immediately related to E. ravilla (C.L. Koch, 1844), the type species of the genus (Framenau et al. 2010a; T.A. Blackledge unpublished data).

Hogg (1898) described Epeira gracilis, a Larinialike orb-weaving spider collected during the Horn Expedition to Central Australia (e.g. Spencer 1896). Later, this species received a replacement name, Araneus ragnhildae Strand, 1917, as Epeira (=Araneus) gracilis was preoccupied three times (e.g. Bonnet 1955). The holotype of E. gracilis Hogg, lodged in the Museum Victoria, is a penultimate male and an accurate species identification remained impossible before the exhaustive revision of Australian species with "larinoid" somatic morphology (e.g. Framenau and Scharff 2008).

The aim of this study is to establish a new genus, Lariniophora, to accommodate $L$. ragnhildae comb. nov. as the type and only species. Its systematic position within the Araneidae and its affinities to Larinia, Eriophora and Verrucosa are tested by adding it to an updated morphological phylogeny of orb-web spiders (Scharff and Coddington 1997).

\section{MATERIAL AND METHODS}

\section{MORPHOLOGY}

This review is based on an exhaustive examination of Australian museum collections as well as most type material of Australian Araneidae deposited overseas. Descriptions are based on specimens preserved in $70 \%$ ethanol. A male pedipalp was repeatedly soaked in $10 \% \mathrm{KOH}$ and subsequently transferred into distilled water until complete expansion was achieved to explore morphology and topology of sclerites. A female epigyne was prepared for internal examination by submersion in $10 \% \mathrm{KOH}$ for ca. 2 hours. For clarity, the illustrations of male pedipalps and female epigynes omit non-diagnostic setae.

Images were taken with a Leica DFC500 digital camera that that was attached to a Leica MZ16A stereo microscope. Photographs were taken in different focal planes (ca. 70 images) and combined with the Leica Application Suite version 2.5.0R1.

\section{PHYLOGENY}

Scharff and Coddington (1997) presented a comprehensive, albeit admittedly preliminary, cladistic analysis at the tribal and subfamily level of 57 genera of orb-web spiders from the family Araneidae and 13 outgroup terminals (70 taxa in total). This analysis was based on 82 characters, 73 morphological and 9 behavioural (data matrix available from TreeBASE (www.treebase.org; verified 18 February 2009). Some codings within the Nephilidae were amended here following Kuntner $(2006,2007)$ and Kuntner et al. (2008): character 40 (sustentaculum: coded (1) present instead of (0) absent for Nephila and Nephilengys); character 41 (carapace: coded (0) hirsute instead of (1) glabrous for Nephila); character 50 (lateral and median eyes separation: coded (1) wide instead of (0) narrow for both Nephila and Nephilengys); character 51 (posterior median eyes with canoe tapetum: coded (0) absent instead of (1) present for Nephilengys).

Lariniophora was subjected to an analysis based on this amended data matrix resulting in 71 terminal taxa. Coding followed the methods described in Scharff and Coddington (1997) and was straightforward for most characters of Lariniophora. A justification of the character coding can be found in the descriptive part of the genus within the taxonomic section of this study below.

The phylogenetic analysis was performed with TNT version 1.1 (Goloboff et al. 2003). I used the "Traditional Search" option with number of replicates ('repls') = 100 , 'trees to save per replications' $=10,000$ (with the maximum trees in memory set to $1,000,000$ ), and 'collapse trees after the search' to exclude unsupported dichotomous trees. Suboptimal trees (shorter than minimal trees) were discarded. Trees were illustrated using WinClada vers. 1.00.08 (Nixon 2002).

\section{ABBREVIATIONS}

Morphology: AL (AW), abdomen length (width); ALE (AME) anterior lateral (median) eyes; CL (CW), carapace length (width); PLE (PME), posterior lateral (median) eyes; TL, total length.

Collections: AM, Australian Museum, Sydney (Australia); QM, Queensland Museum, Brisbane (Australia); NMV, Museum Victoria, Melbourne (Australia); SAM, South Australian Museum, Adelaide (Australia); WAM, Western Australian Museum, Perth (Australia); ZMUC, Zoological Museum, University of Copenhagen (Denmark).

\section{RESULTS}

Only a single species of Lariniophora was found despite an exhaustive examination of all available araneid material in Australian collections and significant collections overseas (including the museums in London, 
Berlin and Hamburg); a total of almost 10,000 records of Australian Araneinae was identified as part of the current revision of Australian Araneinae (VWF and N. Scharff, unpublished data). Based on somatic and morphological characters, L. ragnhildae cannot be placed in any currently known orb-web spider genus (for Australia see Davies 1988 and more recent studies listed above), nor in any of the many currently recognised undescribed genera of this continent justifying the establishment of a monotypic genus.

\section{PHYLOGENY}

Lariniophora scored as follows in Scharff and Coddington's (1997) morphological data matrix (“_"= inapplicable): $0111110000|0000011110|-$ $100000110|0011001011| 0000100010 \mid 110000$ $000|0001000100| 2101000000 \mid 00$. The phylogenetic analysis in TNT found 144 trees of minimum length $1=288$ in only 17 out of 100 runs suggesting a high level of character conflict as already reported from the original analysis (Scharff and Coddington 1997). The strict consensus tree $(1=358, \mathrm{CI}=27, \mathrm{RI}=66)$ collapsed 18 nodes, including the basal nodes of Scharff and Coddington's (1997) original "clade 53" that included Eriophora and Verrucosa in addition to Cyclosa Menge, 1866 and Araniella Chamberlin and Ivie, 1942 (Figure 1). However, Lariniophora grouped in a clade with Eriophora in the strict consensus topology (Figure 1).

Characters supporting the sister group relationship of Lariniophora and Eriophora included the presence of strong macrosetae on tibia II in males (character 2), the presence of a paramedian apophysis (character 18), the presence of a stipes (character 19), the elongated scape (character 29) and the number of trichobothria on metatarsus IV (character 37), although all of these were homoplasious within the framework of this analysis.

\section{DISCUSSION}

The phylogenetic analysis of the Araneidae by Scharff and Coddington (1997) must be regarded as preliminary, however it provides a very good starting point for exploring intergeneric relationships and subfamily affinities of the Araneidae. The inclusion of Lariniophora to this analysis incontrovertibly showed that this genus, despite somatic similarities, is not related to Larinia and allied genera, but is more closely related to Eriophora. The sister group relationship of Lariniophora and Eriophora within the scope of the analysis is supported by mainly genitalic characters including the presence of a paramedian apophysis (character 18). However, coding this character and the presence/absence of a proximal lobe of the conductor (character 8) provided some problems. The paramedian apophysis (originally named in Eriophora by Comstock (1910)) clearly originates at the base of the conductor both in Lariniophora and Eriophora and therefore both characters could be regarded equivalent. Levi (1976) had already suggested that the paramedian apophysis is fused proximally to the conductor in Verrucosa and other genera (Levi 1976, 1985), but Scharff and Coddington (1997) coded a paramedian apophysis in Verrucosa as absent. Scharff and Coddington (1997) also noted substantial homoplasy for both characters and stated (p. 411): "Without commenting on its relation to the paramedian apophysis, one can see (...) that even as an independent character, 'conductor with lobe' contains relatively little phylogenetic information." It is far beyond the scope of this study to solve homology hypotheses for the paramedian apophysis in Araneidae. In respect to characters 8 and 18, I have here coded Lariniophora as Eriophora in Scharff and Coddington's (1997) character matrix based on a detailed examination of the male pedipalp in both genera $(2 \hat{\jmath}, 3$, Eriophora ravilla, WAM T77436-T77440, examined).

In a similar phylogenetic analysis based on Scharff and Coddington's (1997) data matrix, representatives of the Australasian orb-weaving spider genus Backobourkia Framenau, Dupérré, Blackledge and Vink 2010 were placed, like Lariniophora, in a clade with Eriophora and Verrucosa (Framenau et al. 2010a), apparently supporting the former placement of these spiders in Eriophora (e.g. Court and Forster 1988). In contrast, a molecular analysis based on a fragment of the mitochondrial gene cytochrome c oxidase subunit 1 (COI) data clearly supported Backobourkia as member of a clade of other Australasian genera with vastly different morphology, such as Anepsion Strand, 1929 and Novakiella Court and Forster, 1993 (Framenau et al. 2010a) and not immediately related to Eriophora (represented by the type species of Eriophora, E. ravilla). Morphological synapomorphies of Backobourkia that were not considered in Scharff and Coddington's (1997) analysis supported the validity of the genus and illustrated the preliminary nature of the dataset with respect to Australasian Araneinae. Likewise, although Lariniophora is placed in a clade with Eriophora in the current analysis based on Scharff and Coddington's (1997) dataset, somatic and genitalic characters are vastly different to true Eriophora and other "eriophorine" genera justifying the establishment of a new genus.

The holotype of Epeira gracilis, here reviewed as $L$. ragnhildae, is an immature male and it is difficult to undoubtedly identify this specimen taking the somatic similarities of this species with true Larinia into account (e.g. Framenau and Scharff 2008). However, the distribution of L. ragnhildae supports the identity of this species as proposed here. In Australia, true 


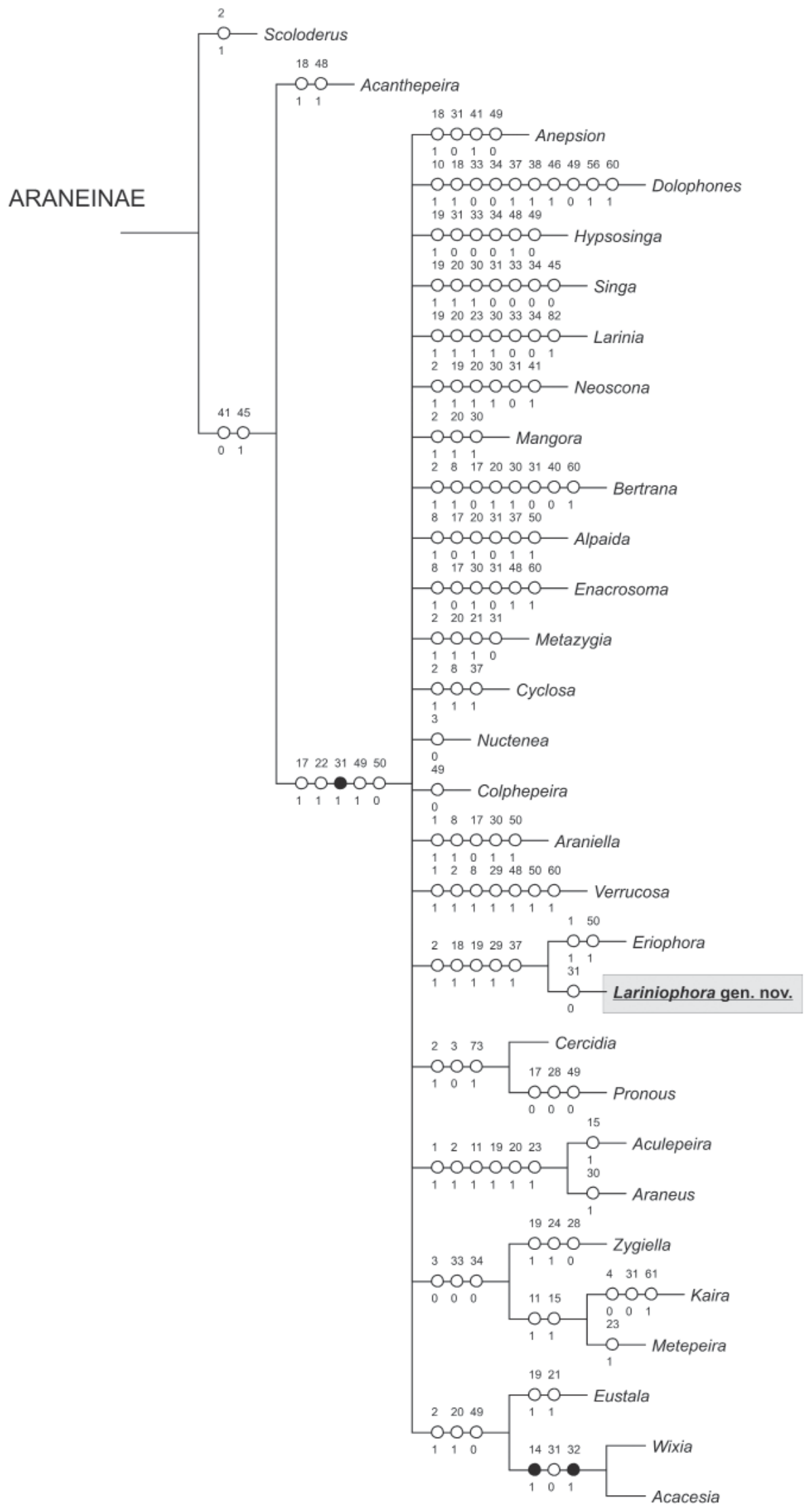

FIGURE $1 \quad$ Systematic position (strict consensus tree) of Larinophora added to the phylogenetic analysis of Scharff and Coddington (1997). Illustrated are only the Araneinae ("clade 41" of Scharff and Coddington (1997)). Open circles denote homoplasious character changes, full circles denote non-homoplasious character changes. Numbers above characters changes refer to the original numbering in Scharff and Coddington (1997), numbers below indicate character state change. 
Larinia are generally found along the coast with only Larinia phthisica (L. Koch, 1871) recorded from a single locality in the arid centre in South Australia (Framenau and Scharff 2008). In contrast, L. ragnhildae is mainly found in the arid zone (Figure 10), including records close to the type locality of Epeira gracilis in the Northern Territory. This leaves little doubt that $L$. ragnhildae is the species reviewed here, providing a taxonomic solution for the immature type that avoids the designation of Araneus ragnhildae as nomen dubium and the description of a new species almost certainly named before.

\section{TAXOMOMY}

\section{Family Araneidae Clerck, 1758}

Subfamily Araneinae Clerck, 1758

Lariniophora gen. nov.

\section{TYPE SPECIES}

Araneus ragnhildae Strand, 1917 (replacement name for Epeira gracilis Hogg, 1898).

\section{DIAGNOSIS}

Lariniophora belongs to the "coxal hook clade" within the orb-web spider subfamily Araneinae (see Scharff and Coddington 1997). Based on the phylogenetic analysis above, it has closest affinities to the genus Eriophora (e.g. Levi 1970), but differs distinctly by a combination of somatic and genitalic characters. In contrast to Eriophora (including Australian species currently placed in Eriophora, E. biapicata (L. Koch, 1871), E. transmarina (Keyserling, 1865) and E. pustulosa (Walckenaer, 1842)), Lariniophora are orb-web spiders with an elongated, narrow abdomen which is at least twice as long as wide, whereas it is less than $1.5 \mathrm{x}$ as long as wide in Eriophora (Levi 1970; Davies 1980; Court and Forster 1988). The abdomen of Lariniophora lacks any tubercles, which are prominent in the anterolateral region of the abdomen in Eriophora. Eriophora pustulosa has additional postero-dorsal tubercles above the spinnerets (e.g. Court and Forster 1988). The median apophysis is much shorter in Lariniophora than in any Eriophora and carries a weakly branched process centrally that is lacking in the latter. The structure of the female epigyne differs from that of Eriophora by the presence of an elevated plate (Figures 6-8).

Male Lariniophora differ from Larinia in, amongst other features, the presence of a paramedian apophysis in the male pedipalp (lacking in Larinia), the presence of a single strong macroseta on the pedipalp patella (two macrosetae in Larinia), and the inflated terminal apophysis (lamellar in Larinia) (e.g. Framenau and Scharff 2008). Female Lariniophora have an elevated epigyne plate (not elevated in Larinia); the epigyne of Lariniophora is slightly longer than wide with a narrow scape, whereas it is much wider than long in Larinia with a broad scape that has a terminal pocket (e.g. Framenau and Scharff 2008).

\section{DESCRIPTION}

(Numbering in square brackets refers to the characters of Scharff and Coddington's (1997) phylogenetic analysis. For example, "[28:1]" refers to character 28 and was coded with character state 1.)

Medium-sized (TL ca. 4-8mm), elongated orb-web spiders, males of similar size as females [61:0]. Carapace longer than wide [42:0; 47:0; 48:0], pear-shaped [43:0], with cephalic region relatively narrower in males than in females; surface glabrous but with some white setae mainly in cephalic region [41:0]. Fovea longitudinal in males, a roundish pit in females that somewhat extends anteriorly. Anterior median eyes largest, their row wider that that of posterior median eyes [49:1], row of posterior eyes recurved [54:0]; lateral eyes touching and only a narrow distance from median eyes [50:0]; posterior median eyes with narrow, canoe-shaped tapetum [51:1; 52:1]. Sternum longer than wide, glabrous, with only few setae. Labium wider than long. Endites of male with lateral tooth [45:1]. Chelicerae relatively weak, in particular in males [44:0]; 2 (males) or 3 (females) promarginal teeth, 1 (males) or 2 (females) retrolateral teeth. Leg formula I $>$ IV $>$ II $>$ III (males) or I $>$ II $>$ IV $>$ III (females); tibiae II of males darker and stronger than tibiae I and with heavier spination [1:0; $2: 1]$; coxae I of males with hook $[33: 1 ; 34: 1]$, one normal macroseta on coxae IV in males [32:0]. Abdomen much longer than wide [59:0; 60:0], extends posteriorly beyond spinnerets, without specialised setae, sigillae, condyles or other specific structures [55:0; 56:0; 57:-; 58:0; 60:0; 65:0; 66:0; 67:1].

Cribellum and paracribellum absent [68:1; 71:2]; anterior spinneret piriform bases normal [69:0], the piriform spinning field fully developed [70:0]; posterior median spinneret ampullate nubbins and aciniform brushes present [72:1; 73:1].

Male pedipalp femora with tubercle [3:1] and patellae with one strong macroseta [4:1]. Paracymbium simple and rounded [6:1]. Conductor large ovoid with basal hook that rests beside the short and stout embolus [8:0; 9:0] (Figures 4-5, 9). Median apophysis comparatively short, with a basal arch over the radix margin and a central, weakly branched process $[10: 0 ; 11: 0 ; 12: 0$; $13: 0 ; 14: 0 ; 15: 0]$. Radix [16:1], distal haematodocha [17:1] and stipes [19:1] present. Paramedian apophysis present [18:1], its end oval-shaped and truncated apically. Subterminal apophysis absent [20:0; 21:-]. Terminal apophysis large bubble-shaped with pointed tip [22:1]. Embolus short and stout, without cap [23:0] and oriented in clockwise direction [24:0].

Female epigyne strongly sclerotised, the plate elevated from the abdomen $[25: 0 ; 26: 0]$ (Figures 6-8). Scape weak, much longer than wide and armed with few 
setae [28:1; 29:1; 30:0; 31:0]. Copulatory openings near anterior end of the epigynal plate. Sperm-ducts form the shape of a lyre; spermathecae spherical.

The web-building behaviour of Lariniophora has not been observed as part of this study but anecdotal evidence taken from labels with museum specimens suggest the construction of a conventional orb-web, as which the behaviour was coded here $[74: 1 ; 75: 0 ; 76: 0$; 77:0; 78:0; 79:0; 80:0; 81:0; 82:0].

\section{ETYMOLOGY}

The generic name is a compound noun constructed from two araneid genera with which the genus shares morphological similarities, Larinia and Eriophora. The gender is feminine.

\section{Lariniophora ragnhildae (Strand 1917) comb. nov.}

Figures $1-2,4-10$

Epeira gracilis Hogg, 1896: 311, 317-318, plate 24, fig. 2 (preoccupied by Epeira gracilis Walckenaer, 1805, Epeira gracilis Keyserling, 1865 and Epeira gracilis Menge, 1879).

Araneus gracilis (Hogg): Rainbow, 1911: 186.

Aranea ragnhildae Strand, 1917: 71 (replacement name for Epeira gracilis Hogg 1896); Roewer, 1942: 832.

Araneus ragnhildae Strand: Bonnet, 1955: 580-581.

\section{MATERIAL EXAMINED}

\section{Holotype}

Australia: Northern Territory: Penultimate $\delta$, labelled "Rudalls Creek" [2350'S, $132^{\circ} 25^{\prime} \mathrm{E}$, Northern Territory], Horn Expedition, 1894 (NMV K932).

\section{Other material examined}

Australia: Northern Territory: 1 ${ }^{\lambda}, 1$, E of Tempe Downs, 2426'S, $132^{\circ} 44^{\prime \prime E}$ (SAM NN26674-5); 1 , Uluru National Park, $29 \mathrm{~km}$ ESE. of Uluru, 2520'50”'S, 13121'26" E (AM KS59133). Queensland: 1 O, 40

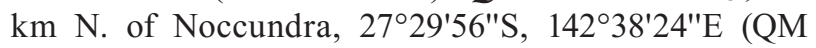
S51149). South Australia: 1 Oे, 9.4 km SE of Maryinna

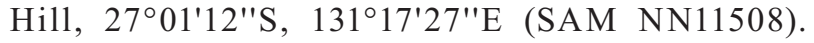

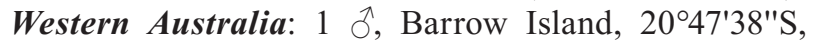
$115^{\circ} 27^{\prime} 34^{\prime \prime E}$ (ZMUC); 1 今, Barrow Island, 2046'59"S, $115^{\circ} 27^{\prime} 03^{\prime \prime E}$ (ZMUC); 1 $\mathrm{o}^{\wedge}$, Barrow Island, Chevron Texaco Camp, 20 49'43"S, 115²6'36"E (ZMUC); 1 ${ }^{\lambda}$, Canning Stock Route, Well 23, $23^{\circ} 05^{\prime} \mathrm{S}, 123^{\circ} 13^{\prime} \mathrm{E}$ (WAM T74425); $1 \hat{\jmath}$, Cloudbreak Mining Lease, Chichester Range, $22^{\circ} 18^{\prime} 31^{\prime \prime S}, 119^{\circ} 22^{\prime} 42^{\prime \prime} \mathrm{E}$ (WAM T83387); 1 ㅇ, Cloudbreak Mining Lease, Chichester Range, $22^{\circ} 17^{\prime} 39^{\prime \prime} \mathrm{S}, 119^{\circ} 22^{\prime} 25^{\prime \prime} \mathrm{E}$ (WAM T82785); $1 \hat{\partial}$, Cloudbreak Mining Lease, Chichester Range, $22^{\circ} 17^{\prime} 21^{\prime \prime S}, 119^{\circ} 22^{\prime} 33^{\prime \prime E ~(W A M ~ T 83282) ; ~} 1$ ô, Exmouth Gulf, $48 \mathrm{~km}$ NW. of Yanry Homestead, $22^{\circ} 05^{\prime} 24 " \mathrm{~S}$, 114²0'12"E (WAM T74416); 1 ô, Gahnda Waterhole,
$100 \mathrm{~km} \mathrm{~W}$. Warburton, $26^{\circ} 36^{\prime} \mathrm{S}, 125^{\circ} 52^{\prime} \mathrm{E} ; 1$ (WAM T75263); $1 \partial^{\wedge}, 1$ juvenile, Lofty Range, $24^{\circ} 16^{\prime} \mathrm{S}, 119^{\circ} 22^{\prime} \mathrm{E}$ (WAM T74431); 3 ${ }^{\lambda}$, Mardathuna Homestead, $7.7 \mathrm{~km} \mathrm{W.}$ on road to North-West Coastal Highway, N. side of road, $24^{\circ} 25^{\prime} 43^{\prime \prime S}, 14^{\circ} 30^{\prime} 01^{\prime \prime E}$ (WAM T73666, T73670); $1 \jmath^{\lambda}$, Mardathuna Homestead, $5.6 \mathrm{~km}$ E. on road to Binthalya, $\mathrm{N}$. side of road, $24^{\circ} 26^{\prime} 36^{\prime \prime} \mathrm{S}, 114^{\circ} 30^{\prime} 42^{\prime \prime} \mathrm{E}$ (WAM T73669); 2 , Mardathuna Homestead, 11.8 km W. on road to North-West Coastal Highway, S. side of road,

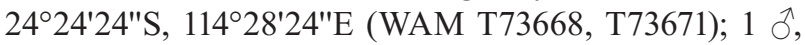
Mount Keith Mine, $15.5 \mathrm{~km}$ E. of Lake Way Homestead, 26 $6^{\circ} 7^{\prime} 41^{\prime \prime S}, 120^{\circ} 37^{\prime} 22^{\prime \prime} \mathrm{E}$ (WAM T75632); $1 \lambda$, Nerren Nerren Station, $27^{\circ} 03^{\prime} 24^{\prime \prime}$ S, 114 $34^{\circ} 23^{\prime \prime}$ E (WAM T73672); 1 ô, Queen Victoria Spring Nature Reserve, $30^{\circ} 14^{\prime} \mathrm{S}, 123^{\circ} 41^{\prime} \mathrm{E}$ (WAM T52698); $1 \overbrace{}^{\Uparrow}$, Woodleigh Station, Woodleigh-Byro Road, $20.3 \mathrm{~km} \mathrm{E}$. of NorthWest Coastal Highway, $26^{\circ} 12^{\prime} 30^{\prime \prime} \mathrm{S}, 114^{\circ} 34^{\prime} 35^{\prime \prime} \mathrm{E}$ (WAM T73667); 1 गे, Woodstock Station, $21^{\circ} 36^{\prime} 35^{\prime \prime} \mathrm{S}$, 118 59'16"E (WAM T75264); 1 ○, Woodstock Station, $21^{\circ} 36^{\prime} 25^{\prime \prime} \mathrm{S}, 119^{\circ} 01^{\prime} 50^{\prime \prime} \mathrm{E}$ (WAM T74716).

\section{DIAGNOSIS}

As per genus.

\section{DESCRIPTION}

Male (Gahnda Waterhole, $100 \mathrm{~km} \mathrm{W.} \mathrm{of} \mathrm{Warburton,}$ WAM T75263)

Carapace (Figure 2). Light yellow-brown; black and narrow median band and olive-grey pigmentation in anterior half; fovea longitudinal; covered with few white setae which are denser around the median eyes; two long bristles between the AME.

Sternum. Olive-grey pigmented, two longitudinal yellow-brown spots in anterior half.

Labium. Olive-grey pigmented, anterior part forms a nearly semicircular white rim.

Endites. Yellow-brown, olive-grey pigmentation basally; strong basal hook opposing groove in pedipalp femora.

Chelicerae. Yellow; some grey pigmentation basally and one small grey spot on each chelicerae centrally; two promarginal teeth, one retromarginal tooth.

Legs. Yellow-brown with irregular, spotty olive-grey pigmentation. Patellae and tibiae II brown, darker, stronger and with stronger spination than patellae and tibiae I; coxae I with basal hook.

Abdomen. Much longer than wide, the posterior tip extends beyond the spinnerets; distinct olive-grey folium that incorporates some irregular patterning (Figure 1). Venter centrally olive-grey with four pair of indistinct lighter patches. Spinnerets brown.

Pedipalps (Figures 4-5, 9). Median apophysis with two-pronged central process; embolus short and stout; terminal apophysis bulbous.

Measurements. TL 6.30, CL 2.67, CW 1.76. Eyes: AME 0.17, ALE 0.08, PME 0.11, PLE 0.10. Row of eyes: 

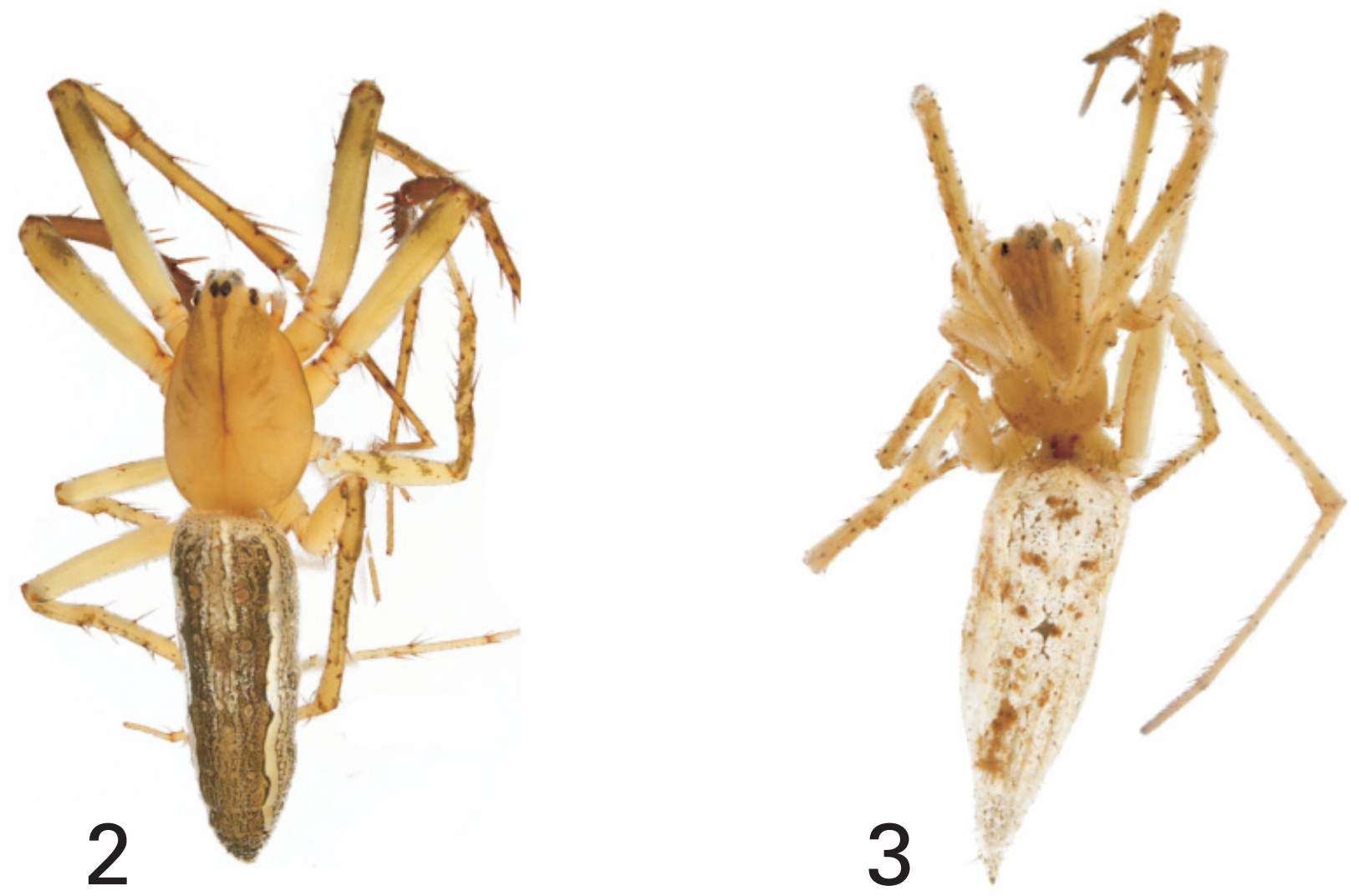

FIGURES 2-3 Lariniophora ragnhildae (Strand): 2, Male from Gahnda Waterhole, Western Australia (WAMT75263), dorsal view (TL $6.30 \mathrm{~mm}$ ); 3, Female from Cloudbreak Mining Lease, Chichester Range, Western Australia (WAM T82785), dorsal view (TL $7.72 \mathrm{~mm}$ ).

AME 0.46, ALE 0.75, PME 0.26, PLE 0.81. Clypeus height 0.12 . Sternum (length/width) $1.33 / 1.09$. Labium (length/width) $0.27 / 0.33$. AL 3.64, AW 1.39. Legs: Lengths of segments (femur + patella/tibia + metatarsus + tarsus $=$ total length): Pedipalp $0.55+0.42+-+0.79=$ 1.76 , I $2.61+4.12+3.09+1.15=10.97$, II $2.24+3.09+$ $2.24+0.97=8.54$, III $1.64+1.94+1.15+0.58=5.30$, IV $2.06+3.33+3.09+1.00=9.48$

Variation. Size (range, mean \pm s.d.): TL $4.23-6.92$, $5.34 \pm 0.76 ;$ CL $2.31-2.77,1.52 \pm 0.17 ;$ CW $1.46-1.85$, $1.64 \pm 0.11 ; \mathrm{n}=13$.

\section{Female (Cloudbreak Mining Lease, Chichester Range; WAM T82785).}

Carapace (Figure 3). As male; fovea a roundish pit that extends somewhat anteriorly.

Sternum. Light brown with light, faint and irregular median band; covered with few white setae.

Labium. Brown basally, anterior part forms a nearly semicircular white rim.

Chelicerae. Yellow; covered with few brownish setae; three promarginal teeth, with the two apical ones larger than the basal one, two retromarginal teeth with the basal one somewhat larger.

Legs. Uniformly yellow, dark spots at base of setae.

Abdomen. Yellow, with faint outline of folium (Figure $2)$. Venter and spinnerets light brown

Epigyne (Figures 6-8). Epigyne plate elevated from the venter; narrow light scape with few setae. Copulatory openings at anterior end of elevated plate; spermathecae spherical.

Measurements. TL 7.72, CL 2.55, CW 1.41. Eyes: AME 0.15, ALE 0.11, PME 0.09, PLE 0.08. Row of eyes: AME 0.41, ALE 0.77, PME 0.26, PLE 0.83. Clypeus height 0.05 . Sternum (length/width) 1.28/0.75. Labium (length/width) $0.27 / 0.41$. AL 4.70, AW 2.34. Legs: Lengths of segments (femur + patella/tibia + metatarsus 

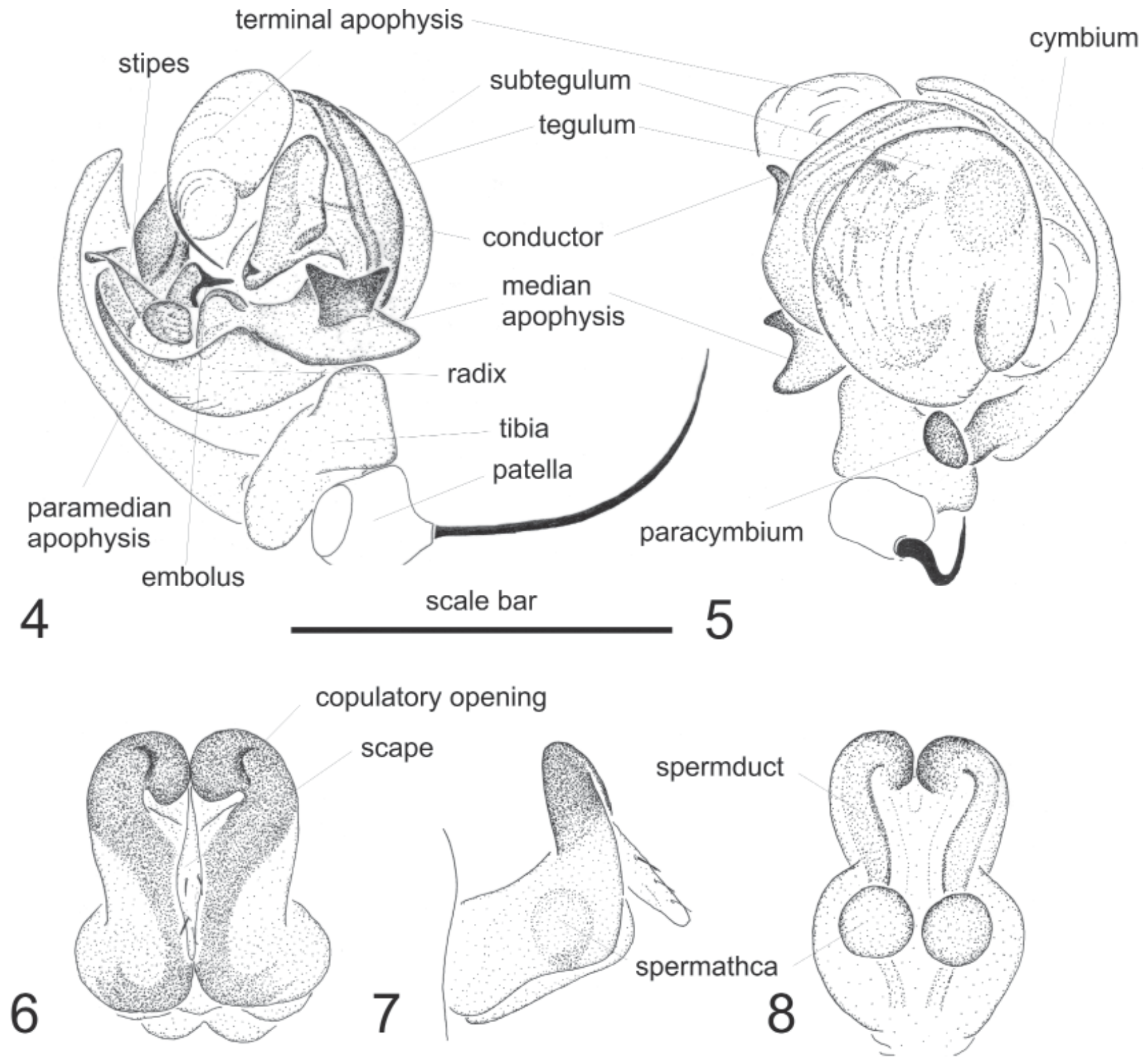

FIGURES 4-8 Lariniophora ragnhildae (Strand). 4-5, left pedipalp (4, retrolateral, 5, ventral view) of male from Gahnda Waterhole, Western Australia (WAM T75263); 6-8, epigyne (6, ventral, 7, lateral, 8, posterior view (cleared in 10\% EtOH)) of female from Uluru National Park, 29 km ESE. of Uluru, Northern Territory (AM KS59133). Scale bar: 4-5, $0.57 \mathrm{~mm}$; 6-8, $0.61 \mathrm{~mm}$.

+ tarsus $=$ total length): Pedipalp $0.54+0.54+-+0.63$

$=1.70$, I $2.30+3.74+3.09+1.00=10.13$, II $1.88+3.17$

$+2.24+0.92=8.22$, III $1.38+1.62+1.10+0.66=4.77$,

IV $1.78+3.40+3.01+1.00=9.19$.

\section{REMARKS}

Hogg (1898, p. 318) lists "Valley of the Stevenson River" as the type locality, possibly referring to the valley of the Stevenson Creek between Dalhousie Springs and Oodnadatta (see Spencer 1986, p. 15). I consider this a transcription error as this locality is in contrast to the label found with the holotype, which clearly states "Rudall Creek", a waterway west of Hermannsburg and much further north than Stevenson
Creek. Both localities, however, fall within the current known distribution of L. ragnhildae. As the holotype is immature, the species is here redescribed based on more recently collected, mature specimens.

\section{DISTRIBUTION}

This species occurs mainly in the arid zone of Western Australia, also known from Northern Territory, Queensland and South Australia (Figure 10).

\section{LIFE HISTORY AND HABITAT PREFERENCES}

Mature males were generally found between mid February and October, and females between March and 


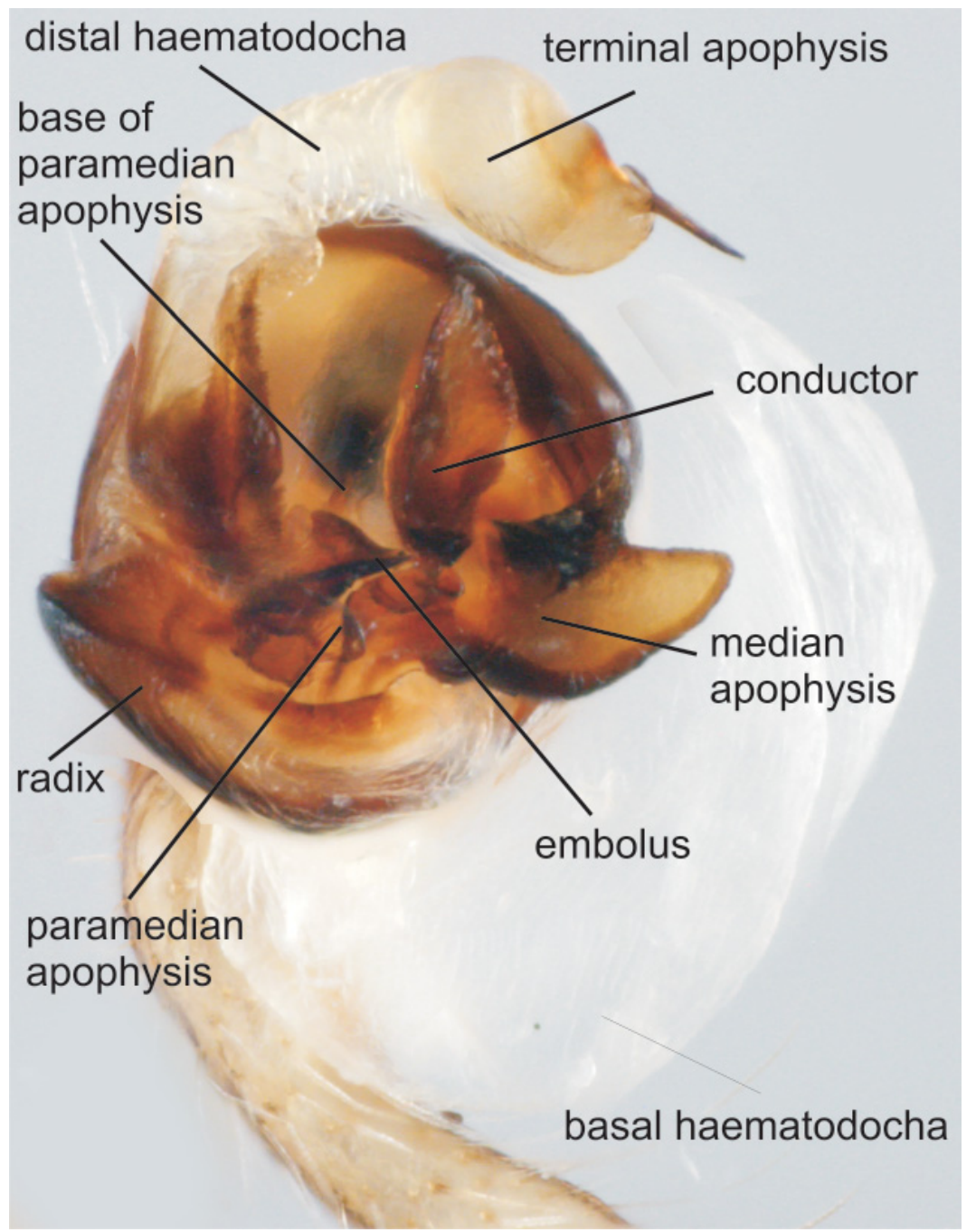

FIGURE 9 Lariniophora ragnhildae (Strand): expanded left pedipalp of male from Well No. 23, Canning Stock Route, Western Australia (WAM T74425).

July suggesting $L$. ragnhildae to be a winter-mature spider. This may also explain the low numbers of females in collections as surveys are carried out rarely in winter.

Lariniophora ragnhildae was repeatedly found during a survey of the southern Carnarvon Basin in Western Australia ("Genus 2, sp. 1" in Harvey et al. 2000, Table 2). Here it was collected in areas with low shrublands, for example Acacia spp. and Grevillea spp., over Triodia rigidissima grassland (Burbidge et al. 2000, Appendix A).

\section{ACKNOWLEDGEMENTS}

Foremost, I am indebted to Nikolaj Scharff for many enlightening insights into araneid systematics, phylogenetic analyses in general, technical advice and financial support during stays in 2007 and 2008 at the Zoological Museum of the University of Copenhagen.
In this context, Tamás Szüts (currently California Academy of Science) and Jan Pedersen are also thanked for never-ending help and support. I thank all curators, collection managers and museum staff who assisted in accessing their collections either as loan or during visits to their respective institutions and by providing access to their databases (in no particular order): Peter Lillywhite, Richard Marchant and Ken Walker (NMV), Owen Seeman and Robert Raven (QM), Barbara Baehr (QM), Graham Milledge and Helen Smith (AM) and David Hirst (formerly SAM). This study would have been impossible without the support of these institutions and their enthusiastic personnel. Laura Leibensperger (Museum of Comparative Zoology, Cambridge) kindly provided material of Eriophora ravilla and other Nearctic Eriophora for comparative analysis. I am thankful to Helen Smith (AM) and Nikolaj Scharff (ZMUC) whose detailed and constructive comments 


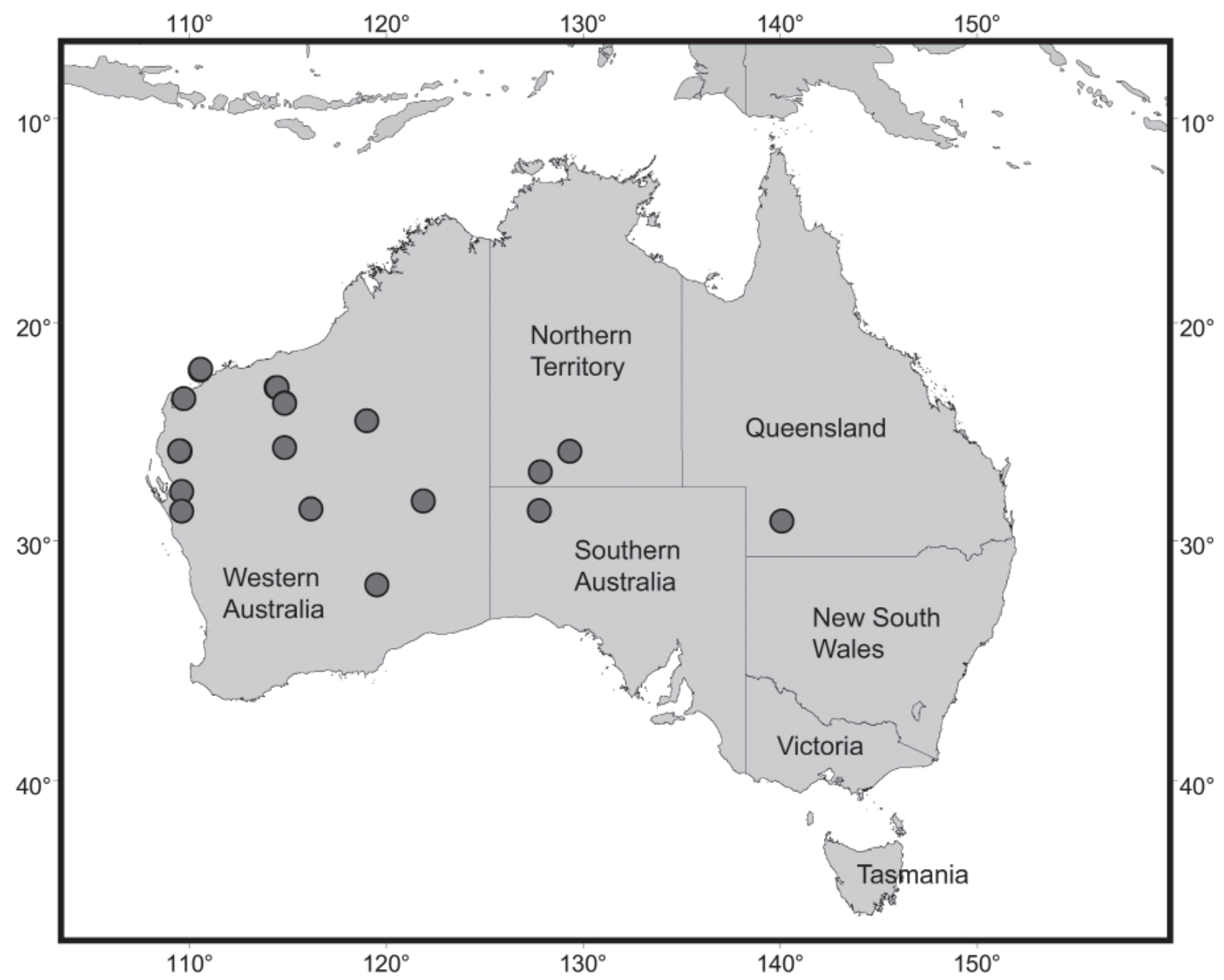

FIGURE 10 Distribution records of Lariniophora ragnhildae (Strand) in Australia $(n=27)$.

greatly enhanced this manuscript. This study was financially supported by the Australian Biological Resources Study (ABRS) (grant no. 205-24; 20052008) to VWF and Nikolaj Scharff (Zoological Museum, University of Copenhagen). I received funding from BHP Billiton Iron Ore when finalising this manuscript.

\section{REFERENCES}

Bonnet, P. (1955). Bibliographia Araneorum. Analyse Méthodique de Toute la Littérature Aranéologique Jusqu'en 1939. Tome II. Douladoure: Toulouse.

Burbidge, A.H., Harvey, M.S. and McKenzie, N.L. (eds) (2000). Biodiversity of the southern Carnarvon Basin. Records of the Western Australian Museum, Supplement 61. Western Australian Museum: Perth.

Comstock, J. (1910). The palpi of male spiders. Annals of the Entomological Society of America 3: 161-185.

Court, D.J. and Forster, R.R. (1988). Araneidae-Araneinae. Otago Museum Bulletin 6: 68-124.

Davies, V.T. (1980). Two large Australian orb-weaving spiders, Eriophora transmarina (Keyserling 1865) and Eriophora biapicata (L. Koch 1871). Memoirs of the Queensland Museum 20: 125-133.
Davies, V.T. (1988). An illustrated guide to the genera of orbweaving spiders in Australia. Memoirs of the Queensland Museum 25: 273-332.

Framenau, V.W. (2008). The male of the orb-weaving spider Cyrtophora unicolor (Araneae, Araneidae). Journal of Arachnology 36: 131-135.

Framenau, V.W. and Scharff, N. (2008). The orb-weaving spider genus Larinia in Australia (Araneae: Araneidae). Arthropod Systematics and Phylogeny 66: 227-250.

Framenau, V.W. and Scharff, N. (2009). Cyrtobill darwini, a new species in a new orb-weaving spider genus from northern Australia (Araneae: Araneidae: Cyrtophorinae). Records of the Western Australian Museum 25: 315-328.

Framenau, V.W., Scharff, N. and Levi, H.W. (2009). Not from "Down Under": new synonymies and combinations for orbweaving spiders (Araneae: Araneidae) erroneously reported from Australia. Zootaxa 2073: 22-30

Framenau, V.W., Dupérré, N., Blackledge, T.A. and Vink, C.J. (2010a). Systematics of the new Australasian orbweaving spider genus Backobourkia (Araneae: Araneidae: Araneinae). Arthropod Systematics and Phylogeny 68: $79-111$.

Framenau, V.W., Scharff, N. and Harvey, M.S. (2010b). Systematics of the Australian orb-web spider genus 
Demadiana with comments on the generic classification of the Arkyinae (Araneae, Araneidae). Invertebrate Systematics 24: 1-33.

Goloboff, P., Farris, J. and Nixon, K. (2003). T.N.T.: Tree Analysis Using New Technology. Program and documentation available from the authors, and at: www. zmuc.dk/publick/phylogeny (verified 18 February 2009).

Grasshoff, M. (1970). Die Tribus Mangorini. I. Die Gattungen Eustala, Larinia s. str, Larinopa n. gen. (Arachnida: Araneae: Araneidae-Araneinae). Senckenbergiana biologica 51: 209-234.

Harmer, A.M.T. and Framenau, V.W. (2008). Telaprocera, a new Australian orb-web spider genus with elongated webs (Araneae: Araneidae). Zootaxa 1956: 59-80

Harrod, J.C., Levi, H.W. and Leibensperger, L.B. (1991). The Neotropical orbweavers of the genus Larinia (Araneae: Araneidae). Psyche 97: 241-265.

Harvey, M.S., Sampey, A., West, P.J. and Waldock, J.M. (2000). Araneomorph spiders from the southern Canarvon Basin, Western Australia: a consideration of regional biogeographic relationships. Records of the Western Australian Museum, Supplement 61: 295-321.

Hogg, H.R. (1896). Araneidae (pp. 309-356). In: Spencer, B. (ed.), Report of the Horn Expedition to Central Australia. Pt. 2. Zoology. Melville, Mullen and Slade: Melbourne.

Kuntner, M. (2006). Phylogenetic systematics of the Gondwanan nephilid spider lineage Clitaetrinae (Araneae, Nephilidae). Zoologica Scripta 35: 19-62.

Kuntner, M. (2007). A monograph of Nephilengys, the pantropical 'hermit spiders' (Araneae, Nephildae, Nephilinae). Systematic Entomology 32: 95-135.

Kuntner, M., Coddington, J.A. and Hormiga, G. (2008). Phylogeny of extant nephilid orb-weaving spiders (Araneae, Nephilidae): testing morphological and ethological homologies. Cladistics 24: 147-217.

Levi, H.W. (1970). The ravilla group of the orbweaver genus Eriophora in North America (Araneae: Araneidae). Psyche 77: 280-302.

Levi, H.W. (1976). The orb-weaver genera Verrucosa, Acanthepeira, Wagneriana, Acacesia, Wixia, Scoloderus and Alpaida north of Mexico. Bulletin of the Museum of Comparative Zoology 147: 351-391.

Levi, H.W. (1985). The spiny orb-weaver genera Micrathena and Chaetacis (Araneae: Araneidae). Bulletin of the Museum of Comparative Zoology 150: 429-618.

Levi, H.W. (1991). The Neotropical and Mexican species of the orb-weaver genera Araneus, Dubiepeira, and Aculepeira (Araneae: Araneidae). Bulletin of the Museum of Comparative Zoology 152: 167-315.

Nixon, K. (2002). Winclada. Version 1.00.08. (Published by the author: Ithaca, New York). Available at: http://www. cladistics.com/aboutWinc.htm (verified 18 February 2009).

Platnick, N.I. (2010). The World Spider Catalog. Version 11. Available at : http://research.amnh.org/entomology/spiders/ catalog/ (verified 19 October 2010).

Rainbow, W.J. (1911). A census of Australian Araneidae. Records of the Australian Museum 9: 107-319.

Roewer, C.F. (1942). Katalog der Araneae von 1758 bis 1940. 1. Band (Methothelae, Orthognatha, Labidognatha: Dysderaeformia, Scytodiformia, Pholciformia, Zodariiformia, Hersiliaeformia, Argyopiformia). Paul Budy: Bremen.

Scharff, N. and Coddington, J.A. (1997). A phylogenetic analysis of the orb-weaving spider family Araneidae (Arachnida, Araneae). Zoological Journal of the Linnean Society 120: 355-434.

Smith, H.M. (2006). A revision of the genus Poltys in Australasia (Araneae: Araneidae). Records of the Australian Museum 58: 43-96.

Smith, H.M. and Levi, H.W. (2010). Review of the genus Micropoltys (Chelicerata: Araneae: Araneidae). Arthropod Systematics and Phylogeny 68: 291-307.

Spencer, B. (1896). Report on the work of the Horn Scientific Expedition to Central Australia. Part I. Introduction, narrative, summary of results, supplement to zoological report, map. Melville, Mullen and Slade: Melbourne.

Strand, E. (1917). Arachnologica varia XIV-XVIII. Archiv für Naturgeschichte 82 (A2): 70-76.

MANUSCRIPT RECEIVED 22 OCTOBER 2010; ACCEPTED 16 DECEMBER 2010. 